\title{
Genetic variability and correlation studies for morphological and yield traits in maize (Zea mays L.)
}

\author{
Abdullah Izzam ${ }^{1}$, Hidayatur Rehman ${ }^{1}$, Amir Sohail ${ }^{1 *}$, Shahzad Ali², \\ Manzoor $^{2}$ and Quaid Hussain ${ }^{1}$ \\ 1. Department of Plant Breeding and Genetics, The University of Agriculture, Peshawar, Khyber Pakhtunkhwa- \\ Pakistan \\ 2. Department of Agronomy, The University of Agriculture, Peshawar, Khyber Pakhtunkhwa-Pakistan \\ *Corresponding author's email: amirsohail@aup.edu.pk
}

Citation

Abdullah Izzam, Hidayatur Rehman, Amir Sohail, Shahzad Ali, Manzoor and Quaid Hussain. Genetic variability and correlation studies for morphological and yield traits in maize (Zea mays L.). Pure and Applied Biology. Vol. 6, Issue 4, pp1234-1243. http://dx.doi.org/10.19045/bspab.2017.600131

\begin{tabular}{llll}
\hline \hline Received: 13/05/2017 & Revised: 18/09/2017 & Accepted: 22/09/2017 & Online First: 26/09/2017 \\
\hline \hline
\end{tabular}

\section{Abstract}

This experiment was conducted at the University of Agriculture Peshawar, during spring 2015 to estimate genetic variability in maize genotypes for morphological and yield related traits. The study was laid out in randomized complete block design with three replications using 22 genotypes comprising 20 hybrids and two local checks. Data were taken on days to tasseling, anthesis, silking, anthesis-silking interval, plant height, ear height, flag leaf area, cob length, kernel rows $\mathrm{cob}^{-1}, 100$-kernel weight and grain yield. Significant $(\mathrm{P} \leq 0.01)$ variability among the hybrids was found for all the traits. Mean values for the traits ranged between 49-65(tasseling), 52-70 (anthesis), 52-72 (silking), 0-4 (anthesis silking interval), 161.7-213.5(plant height), 53.898.6(ear height), 422.4-662.5(flag leaf area), 17.2-24.5(cob length), 13.0-17.0(kernel rows $\mathrm{cob}^{-1}$ ), 25.3-38.3(100-kernel weight) and 2770-7500(grain yield). Hybrid-1 performed better for yield and yield associated traits under the tested agro-climatic conditions. Grain yield had significant and positive correlation with ear length $(\mathrm{r}=0.45)$ and non-significant but positive correlation with plant height $(\mathrm{r}=0.23)$, ear height $(\mathrm{r}=0.41)$, flag leaf area $(\mathrm{r}=0.03)$ kernel rows per cob $(\mathrm{r}=0.05)$ and 100 kernel weight $(r=0.21)$. The positive correlations suggested that the desired characters in these hybrids could be improved simultaneously in further maize breeding programs. Based on the result of current studies hybrid ${ }^{-1}$ could be recommended for commercial cultivation of maize hybrids for the agro-climatic condition of Peshawar.

Keywords: Maize (Zea mays L.); Genetic variability; Correlation, Morphological; Yield

Introduction
Maize (Zea mays L.) is the third most important cereal crop after wheat and rice worldwide. Its grain is highly nutritive, with $4-4.5 \%$ fats, $70-72 \%$ carbohydrates, oils 2 $2.8 \%$ and $9.5-11 \%$ proteins [1]. According to Food and Agriculture Organization (FAO) worldwide maize was cultivated over the area of 118 million hectares with an annual production of 600 million metric tons. In Pakistan, maize is the fourth major crop after wheat, cotton, and rice. The area 
under maize cultivation in Pakistan was 1168.5 thousand hectares with a production of 4944.2 thousand tons [2].

Genetic variability for different traits among the maize genotypes is a key factor for crop improvement [3]. High yielding and stable cultivar is the major goal of almost all breeding programs. Uniform performance of genotypes both with low and high yield across different maize environment is desirable and referred as yield stability [4]. The grain yield is a quantative (polygenic) trait in nature, controlled by many genes and also interacts with environmental conditions thus have low heritability [5]. During the evaluation of maize genotypes for grain yield comparison several agronomic traits are taken into consideration. Among these, anthesis silking interval, plant height, ear height, kernel rows per cob, cob length and cob diameter are significantly important [6]. In most of the maize breeding programs genotypes are selected on the basis of desirable combination of traits and not only its yield potential. Hence, yield improvement can be achieved easily through direct selection as well as indirect selection through yield component because of complex nature of a trait [7].

Evaluation of genotypes for traits is an important step towards the development of varieties or hybrids. Breeders usually evaluate advanced breeding material to select superior genotypes for generation advancement or possible release as new variety. Hence it is important to explore relationships among morphological and yield associated characters in maize hybrids [8].This experiment was therefore conducted to investigate the magnitude of genetic variability and trait association of various plant traits with grain yield in maize hybrids.

\section{Materials and methods}

During spring crop season 2015, a set of twenty maize hybrids (Table 1) along with two local checks were evaluated for morphological and yield related traits in Randomized Complete Block (RCB) design using three replications at The University of Agriculture, Peshawar. Each plot consisted of two rows. The row length was $5 \mathrm{~m}$ with $0.75 \mathrm{~m}$ spacing between them. Fifty seeds were planted in each plot on $27^{\text {th }}$, March 2015. Normal culture practices including tillage, hoeing, irrigation, application of fertilizer etc. were performed during whole cropping season.

Data recorded included days to tasseling, anthesis and silking, anthesis-silking interval (ASI), plant height, ear height, flag leaf area, ear length, kernel rows $\mathrm{cob}^{-1}, 100$ kernel weight and grain yield. Data on flowering traits and grain yield were recorded on plot basis while for yield and yield components, the data were taken on a sample of ten plants. Data recorded were subjected to analysis of variance (ANOVA) and correlation coefficients were calculated using computer software SPSS v. 16. Means comparison among the genotypes was carried out following LSD test at 5\% level of probability. 
Table 1. List of hybrids and their pedigree

\begin{tabular}{|c|c|c|c|}
\hline Hybrid & Pedigree & Hybrid & Pedigree \\
\hline 1 & PS-36 $\times$ PSCH-14 & 12 & PSEV-06 $\times$ PSCH-14 \\
\hline 2 & PS-51 $\times$ PSCH-14 & 13 & PSEV-091 $\times$ PSCH-14 \\
\hline 3 & PS-491 $\times$ PSCH-14 & 14 & PSEV-092 $\times$ PSCH-14 \\
\hline 4 & PS-95 $\times$ PSCH-14 & 15 & PSEV-101 $\times$ PSCH-14 \\
\hline 5 & PS-13 $\times$ PSCH-14 & 16 & PSEV-102 $\times$ PSCH-14 \\
\hline 6 & PS-11 $\times$ PSCH-14 & 17 & PSEV-11 $\times$ PSCH-14 \\
\hline 7 & PS-14 $\times$ PSCH-14 & 18 & Sarhad $(W) \times$ PSCH-14 \\
\hline 8 & PS-204 $\times$ PSCH-14 & 19 & Jalal $\times$ PSCH-14 \\
\hline 9 & PS-228 $\times$ PSCH-14 & 20 & Pahari $\times$ PSCH-14 \\
\hline 10 & PS-47 $\times$ PSCH-14 & Check-I & P-30K08 Hybrid $)$ \\
\hline 11 & PS-225 $\times$ PSCH-14 & Check-II & Jalal $($ OPV $)$ \\
\hline
\end{tabular}

\section{Results and discussion}

Days to 50\% tasseling

Mean squares value showed significant $(\mathrm{P} \leq 0.01)$ variation among the maize hybrids for days to tasseling (Table 2). Shah et al. and Abdulla et al. [9, 10] also reported significant $(\mathrm{P} \leq 0.01)$ differences for days to tasseling in maize inbred lines. Mean values ranged from 49 to 65 days (Table 3). Minimum days to $50 \%$ tasseling were recorded for (Check-II) Jalal (49 days), followed by hybrid 8 and 11 (51 days). Hybrid 14 took maximum days to $50 \%$ tasseling (65 days), followed by hybrids 3, 5, 12, 17 and 20 (63 days). Days to tasseling had significant $(\mathrm{P} \leq 0.01)$ positive correlation with days to anthesis $(\mathrm{r}=0.92)$, days to silking $(\mathrm{r}=0.91)$ and anthesis silking interval $(\mathrm{r}=0.38)$. Similarly days to tasseling had a significant $(\mathrm{P} \leq 0.05)$ positive correlation with kernel rows $\operatorname{cob}^{-1}(\mathrm{r}=0.25)$ whereas, non-significant positive association with plant height $(r=0.02)$, ear length $(r=0.03)$ and 100 kernel weight $(\mathrm{r}=0.03)$. On the other hand non-significant negative association with ear height $(r=-0.03)$, flag leaf area $(r=-$ 0.13 ) and grain yield ( $\mathrm{r}=-0.20)$ (Table 4). Our findings are in conformity with Shakoor et al. [11], who also noted negative association of days to tasseling with grain yield in maize genotypes. Early tasseling could cause earlier pollen shedding and silking which ultimately affects the overall maturity period of maize crop.

\section{Days to $50 \%$ anthesis}

Means square values exhibited significant $(\mathrm{P} \leq 0.01)$ variation among the hybrids for days to anthesis (Table 2). Our findings are in line with Sabiel et al. and Ahmad et al. $[12,13]$ who also reported highly significant variation among maize genotypes for days to anthesis. Mean values for this parameter ranged from 51 to 70 days (Table 3). Earliest anthesis (51 days) was observed for Check-II while late anthesis was reported for hybrid 19 (70 days). Days to anthesis had significant $(\mathrm{P} \leq 0.01)$ and positive association with days to tasseling $(r=0.92)$ and days to silking $(\mathrm{r}=0.91)$, whereas, it exhibited nonsignificant association with rests of studied traits (Table 4). Our findings are in correspondence with Duvick et al. [14] who also reported a positive association of days to anthesis with days to anthesis silking interval, plant height, and 100 kernel weight. Days to anthesis is an important character in determining maturity period of maize crop and maize varieties with early maturity are always desirable in multiple cropping system.

\section{Days to 50\% silking}

Mean squares values revealed significant $(\mathrm{P} \leq 0.01)$ variation among the tested hybrids for days to silking (Table 2). Our findings 
are in conformity with Qamar et al. and Rahman et al. [15, 16] who quantified that days to silking, anthesis and anthesis silking interval are generally used by maize breeders as basis of determining maturity duration in maize crop. Mean values ranged from 52 to 72 days (Table 3). Earliest silking was exhibited by hybrid 8 and 13 (52 days), whereas, hybrids 14, 15 and 19 took maximum (72) days to reach silking stage. Days to silking showed significant $(\mathrm{P} \leq 0.01)$ positive association with days to tasseling $(\mathrm{r}=0.91)$, days to anthesis $(\mathrm{r}=0.92)$ and anthesis silking interval $(\mathrm{r}=0.56)$ whereas, it showed non-significant relationship with plant height $(r=0.06)$, ear height $(r=-0.07)$, flag leaf area $(r=-0.11)$, ear length $(r=-0.10)$, kernel rows per cob $(\mathrm{r}=0.25), 100$ kernel weight $(\mathrm{r}=0.13)$ and grain yield $(\mathrm{r}=-0.30)$ (Table 4). Duvick et al. [14] also observed positive relationship between days to silking and anthesis silking interval.

\section{Anthesis-silking interval}

Mean squares value exhibited significant $(\mathrm{P} \leq 0.01)$ differences among the hybrids for anthesis-silking interval (Table 2). Our findings are in correspondence with Rahman et al. [17] who also reported significant differences for anthesis-silking interval among maize populations. Mean values ranged from 0 to 4 (Table 3). Minimum anthesis-silking interval was observed for hybrid 11 and 15 and maximum anthesissilking interval (4) was observed for hybrid 4 and 14. Hybrid 11 and 15 showed 0 ASI. This indicated that pollen shedding and silking were well synchronized in these two hybrids. Anthesis silking interval exhibited significantly positive association with days to silking $(\mathrm{r}=0.56)$ and a non-significant positive correlation with days to tasseling $(\mathrm{r}=0.39)$, days to anthesis $(\mathrm{r}=0.41)$, plant height $(\mathrm{r}=0.06)$, kernel rows per cob $(\mathrm{r}=0.02)$ and 100 grain weight $(\mathrm{r}=0.30)$ while, it had non-significant negative relationships with ear height $(r=-0.14)$, flag leaf area $(\mathrm{r}=-0.14)$, ear length $(\mathrm{r}=-0.04)$ and grain yield ( $\mathrm{r}=-0.28)$ (Table 4$)$. Our results are in contradiction with Shakoor et al. [11], who also stated a positive relationship between anthesis silking interval and grain yield. Synchronization between anthesis and silking leads to higher seed setting and ultimately higher grain yield.

\section{Plant height}

Mean square values exhibited highly significant differences among the maize hybrids for plant height (Table 2). Shah et al. [9] also observed significant differences for plant height. Means ranged from 161.73 to $213.53 \mathrm{~cm}$ (Table 3). Hybrid 6 produced the shortest plants $(16.73 \mathrm{~cm})$ while, hybrid 14 attained maximum plant height (213.53 $\mathrm{cm})$. Maize breeders give special attention to this character in maize breeding because plant height is an important agronomic character that plays role in plant lodging. Semi-dwarf plants are desired, because such plants are resistant to lodging and are fertilizer responsive. Plant height showed significant $(\mathrm{P} \leq 0.01)$ association with ear height $(\mathrm{r}=0.59)$ and kernel rows per cob $(\mathrm{r}=0.57) \quad$ whereas, it displayed nonsignificant positive association was observed with days to tasseling ( $\mathrm{r}=0.02)$ days to anthesis $(\mathrm{r}=0.10)$, silking $(\mathrm{r}=0.06)$ anthesis silking interval $(\mathrm{r}=0.06), 100$ kernel weight $(\mathrm{r}=0.38)$ and grain yield $(\mathrm{r}=0.23)$ (Table 4). Singha and Prodhan [18] also reported that plant height and grain yield had positive correlation.

\section{Ear height}

Mean squares exhibited significant $(\mathrm{P} \leq 0.05)$ differences among the hybrids for ear height (Table 2). Similar findings were also reported by Rahman et al. [16]. Ear height ranged from 53.80 to $98.60 \mathrm{~cm}$ (Table 3). Hybrid 6 revealed minimum $(53.80 \mathrm{~cm})$ ear height while hybrid 14 showed maximum $(98.60 \mathrm{~cm})$ ear height. Ear height had nonsignificant but positive association with ear length $(r=0.20)$, kernel rows per cob 
$(\mathrm{r}=0.20), 100$ kernel weight $(\mathrm{r}=0.10)$ and grain yield $(\mathrm{r}=0.41)$ while, non-significant negative association was showed with days to tasseling $(\mathrm{r}=-0.03)$, anthesis $(\mathrm{r}=-0.03)$, silking $(\mathrm{r}=-0.07)$, anthesis silking interval $(\mathrm{r}=-0.15)$ and flag leaf area $(\mathrm{r}=-0.17)$ (Table 4). Allen et al. [19] observed that ear height indirectly increased grain yield through reduction in lodging.

\section{Flag leaf area}

Mean squares value for flag leaf area among the hybrids displayed highly significant differences (Table 2). Mean values ranged from 422.40 to $662.53 \mathrm{~cm}^{2}$ (Table 3). Smaller flag leaf area $\left(422.40 \mathrm{~cm}^{2}\right)$ was revealed by hybrid 8 while, larger flag leaf area $\left(592.87 \mathrm{~cm}^{2}\right)$ was exhibited by hybrid 20. Flag leaf area had non-significant positive association with ear length $(r=0.024)$, kernel rows per cob $(r=0.03)$ and grain yield $(r=0.03)$. Likewise flag leaf area exhibited non-significant and negative association with days to tasseling ( $\mathrm{r}=-0.13)$, anthesis $(\mathrm{r}=-0.07)$, silking $(\mathrm{r}=-0.11)$, anthesis silking interval $(\mathrm{r}=-0.14)$, plant and ear height ( $\mathrm{r}=-0.16$ and $\mathrm{r}=-0.17$ respectively) whereas, it showed significant $(\mathrm{P} \leq 0.05)$ negative association with 100 kernel weight ( $\mathrm{r}=-46)$ (Table 4). Martin and Russel [20] also reported that grain yield increased with larger flag leaf area.

\section{Cob length}

Mean squares for cob length exhibited significant $(\mathrm{P} \leq 0.01)$ differences among the maize hybrids (Table 2). These results are in a favor of Carlone and Russell [21] who also reported that cob length contributed directly to grain yield. Mean values for cob length ranged from 17.20 to $24.49 \mathrm{~cm}$ (Table 3). Hybrid 16 showed minimum $(17.20 \mathrm{~cm}) \mathrm{cob}$ length and hybrid 3 exhibited maximum $(24.49 \mathrm{~cm})$ cob length. Ear length had significant $(\mathrm{P} \leq 0.05)$ positive association with grain yield $(r=0.45)$ and had nonsignificant positive relationships with days to tasseling $(\mathrm{r}=0.03)$, ear height $(\mathrm{r}=0.12)$, flag leaf area $(r=0.24)$, kernel rows per cob $(r=0.03)$ while with rest of the traits it exhibited non-significant negative association as shown in Table 4. Our findings are in correspondence with Rafiq et al. [22], who observed higher grain yield with larger cob length.

\section{Kernel rows cob $^{-1}$}

Significant $(\mathrm{P} \leq 0.01)$ variations were found for kernel rows $\mathrm{cob}^{-1}$ among the maize hybrids (Table 2). Mean values for kernel rows $\mathrm{cob}^{-1}$ ranged from 13.00 to 17.00 rows per cob (Table 3). Minimum kernel rows $\mathrm{cob}^{-1}$ (13.00) was recorded for Check-I while, maximum kernel rows $\operatorname{cob}^{-1}$ (17.00) was observed for hybrid 1 . Kernel rows cob 1 had significant $(\mathrm{P} \leq 0.01)$ positive association with plant height $(\mathrm{r}=0.57)$ while, with a rest of the characters it had nonsignificant positive correlation (Table 4). Umakanth et al. and Altenbas and Algan $[23,24]$ also reported that kernels rows $\mathrm{cob}^{-1}$ had significant $(\mathrm{P} \leq 0.01)$ and positive association with plant height. They suggested that while doing selection yield improvement ear diameter and kernel rows ear $^{-1}$ should be given more preference.

\section{Kernel weight}

Mean square values revealed significant $(\mathrm{P} \leq 0.01)$ differences among the maize hybrids for 100 kernel weight (Table 2). For 100 kernel weight among maize hybrids mean values ranged from 25.27 to $38.27 \mathrm{~g}$. Minimum 100 kernel weight (25.27 g) was recorded for hybrid 20 whereas, maximum 100 kernel weight (35.27 g) was observed for hybrid 1 as shown in table 3 . Hundred kernel weight exhibited significantly negative association with flag leaf area ( $\mathrm{r}=-$ 0.46) and non-significant but positive association with all the traits except with ear length $(\mathrm{r}=-0.09)$ which had non-significant negative association with 100 kernel weight (Table 4). Rahman et al. [25] also observed a positive association between ear length and 100 kernel weight. Rahman et al. and 
Nizam-ud-din et al. [25, 26] reported that 100 kernel weight and ear length are major contributors to grain yield.

\section{Grain yield}

Statistical analysis showed significant $(\mathrm{P} \leq 0.01)$ variation for grain yield among the maize hybrids (Table 2). Similar findings were also reported by Tahir et al. [27], while comparing yield performance of different maize hybrids. Mean values for grain yield among maize genotypes ranged from 2770 to $7500 \mathrm{~kg} \mathrm{ha}^{-1}$. Hybrid 6 showed minimum grain yield $\left(2770 \mathrm{~kg} \mathrm{ha}^{-1}\right)$ while hybrid 1 exhibited maximum grain yield $\left(7500 \mathrm{~kg} \mathrm{ha}^{-}\right.$

1) (Table 3). Grain yield had significant
$(\mathrm{P} \leq 0.05)$ and positive association with ear length $(r=0.45)$ and non-significant but positive association with plant height $(r=0.23)$, ear height $(r=0.41)$, flag leaf area $(\mathrm{r}=0.03)$, kernel rows per cob $(\mathrm{r}=0.05)$ and 100 kernel weight (0.21). Non-significant but negative association was noted with days to tasseling $(\mathrm{r}=-0.20)$, days to anthesis $(\mathrm{r}=-$ $0.25)$, days to silking $(\mathrm{r}=-0.30)$ and anthesis silking interval $(\mathrm{r}=-0.28)$. Iqbal and Chuhan [28] also observed increased in grain yield due to positive association of grain yield with kernel rows $\mathrm{cob}^{-1}$ and 100 kernel weight.

Table 2. Mean squares of morphological and yield attributing traits in maize hybrids

\begin{tabular}{|l|c|c|c|c|}
\hline Parameters & $\begin{array}{c}\text { Replications } \\
(\mathbf{d f = 2})\end{array}$ & $\begin{array}{c}\text { Genotypes } \\
(\mathbf{d f = 2 1})\end{array}$ & $\begin{array}{c}\text { Error } \\
(\mathbf{d f = 4 2})\end{array}$ & $\begin{array}{c}\text { Coefficient of } \\
\text { variation (\%) }\end{array}$ \\
\hline Days to tasseling & 12.59 & $73.51^{* *}$ & 2.32 & 14.42 \\
\hline Days to anthesis & 10.97 & $85.51^{* *}$ & 5.56 & 3.70 \\
\hline Days to silking & 2.38 & $113.48^{* *}$ & 3.44 & 2.82 \\
\hline $\begin{array}{l}\text { Anthesis silking } \\
\text { interval (ASI) }\end{array}$ & 0.29 & $4.19^{* *}$ & 0.57 & 33.55 \\
\hline Plant height(cm) & 29.78 & $458.45^{* *}$ & 12.31 & 1.92 \\
\hline Ear height(cm) & 390.84 & $256.47^{*}$ & 139.51 & 14.79 \\
\hline Flag leaf area $\left(\mathbf{c m}^{\mathbf{2}}\right)$ & 74.32 & $11732.32^{* *}$ & 472.98 & 4.13 \\
\hline Cob length $(\mathbf{c m})$ & 1.22 & $6.57^{* *}$ & 0.285 & 2.63 \\
\hline Kernel rows cob-1 $\mathbf{( n o )}$ & 1.15 & $2.34 * *$ & 0.58 & 5.29 \\
\hline 100 Kernel weight $\mathbf{( g )}$ & 2.56 & $34.79^{* *}$ & 7.35 & 8.25 \\
\hline Grain yield(kg ha-1) & 113298.59 & $5669481.45^{* *}$ & 62631.19 & 4.94 \\
\hline
\end{tabular}

$*, * *$ significant at $1 \%$ and $5 \%$ levels of probability, respectively 
Table 3. Mean values of 22 maize hybrids for morphological and yield traits

\begin{tabular}{|c|c|c|c|c|c|c|c|c|c|c|c|}
\hline Hybrids & $\begin{array}{l}\text { Days to } \\
\text { tasseling } \\
\text { (days) }\end{array}$ & $\begin{array}{l}\text { Days to } \\
\text { anthesis } \\
\text { (days) }\end{array}$ & $\begin{array}{l}\text { Days to } \\
\text { silking } \\
\text { (days) }\end{array}$ & $\begin{array}{l}\text { Anthesis } \\
\text { silking } \\
\text { interval }\end{array}$ & $\begin{array}{l}\text { Plant } \\
\text { height } \\
(\mathrm{cm})\end{array}$ & $\begin{array}{l}\text { Ear } \\
\text { height } \\
(\mathrm{cm})\end{array}$ & $\begin{array}{l}\text { Flag leaf } \\
\text { area } \\
\left(\mathrm{cm}^{2}\right) \\
\end{array}$ & $\begin{array}{l}\text { Ear } \\
\text { length } \\
(\mathrm{cm})\end{array}$ & $\begin{array}{l}\text { Kernel } \\
\text { rows cob-1 } \\
\text { (no) }\end{array}$ & $\begin{array}{l}100 \text { kernel } \\
\text { weight } \\
\text { (g) }\end{array}$ & $\begin{array}{l}\text { Grain } \\
\text { yield } \\
\left(\mathrm{kg} \mathrm{ha}^{-1}\right)\end{array}$ \\
\hline 1 & 62 & 67 & 68 & 2 & 198.5 & 92.3 & 522.9 & 21.3 & 17.0 & 38.3 & 7500 \\
\hline 3 & 63 & 65 & 67 & 2 & 167.1 & 81.7 & 585.2 & 24.5 & 14.0 & 31.8 & 6483 \\
\hline 4 & 54 & 62 & 66 & 4 & 177.9 & 79.7 & 443.9 & 19.8 & 13.7 & 37.4 & 4993 \\
\hline 5 & 63 & 65 & 68 & 3 & 164.4 & 80.4 & 552.1 & 18.7 & 13.7 & 31.6 & 3225 \\
\hline 8 & 51 & 53 & 52 & 1 & 197.7 & 85.9 & 564.1 & 19.5 & 14.3 & 35.3 & 7008 \\
\hline 9 & 61 & 67 & 69 & 2 & 187.4 & 84.6 & 497.9 & 21.0 & 15.7 & 32.4 & 6007 \\
\hline 10 & 62 & 65 & 66 & 2 & 175.8 & 77.0 & 511.1 & 20.4 & 14.7 & 28.7 & 5435 \\
\hline 11 & 51 & 58 & 58 & 0 & 173.1 & 85.1 & 637.2 & 19.9 & 14.7 & 26.3 & 3378 \\
\hline 12 & 63 & 68 & 69 & 1 & 181.9 & 78.9 & 492.2 & 19.5 & 13.7 & 31.4 & 5742 \\
\hline 17 & 63 & 69 & 70 & 1 & 182.9 & 80.9 & 480.8 & 19.1 & 14.3 & 32.9 & 3981 \\
\hline 18 & 62 & 65 & 68 & 3 & 188.5 & 73.1 & 465.3 & 20.4 & 15.0 & 34.0 & 3317 \\
\hline 19 & 61 & 70 & 72 & 2 & 196.3 & 77.9 & 615.6 & 19.1 & 14.7 & 36.0 & 4378 \\
\hline 20 & 63 & 65 & 68 & 3 & 174.0 & 76.9 & 662.5 & 21.8 & 14.0 & 25.3 & 5208 \\
\hline Check-I & 62 & 66 & 69 & 2 & 172.8 & 89.7 & 495.4 & 22.2 & 13.0 & 32.4 & 5387 \\
\hline check-II & 49 & 51 & 53 & 2 & 189.6 & 85.7 & 535.8 & 21.9 & 14.0 & 32.0 & 5150 \\
\hline Minimum & 49 & 51 & 52 & 0 & 161.7 & 53.8 & 422.4 & 17.2 & 13.0 & 25.3 & 2770 \\
\hline Maximum & 65 & 70 & 72 & 4 & 213.5 & 98.6 & 662.5 & 24.5 & 17.0 & 28.3 & 7500 \\
\hline $\operatorname{LSD}_{(0.05)}$ & 1.45 & 2.24 & 1.77 & 0.72 & 3.34 & 11.24 & 20.69 & 0.51 & 0.72 & 2.58 & 238.08 \\
\hline
\end{tabular}


Table 4. Correlation among different traits in maize hybrids evaluating during 2015

\begin{tabular}{|c|c|c|c|c|c|c|c|c|c|c|}
\hline Traits & $\begin{array}{l}\text { Days to } \\
\text { heading }\end{array}$ & $\begin{array}{l}\text { Days to } \\
\text { anthesis }\end{array}$ & $\begin{array}{l}\text { Days to } \\
\text { silking }\end{array}$ & $\begin{array}{l}\text { Anthesis } \\
\text { silking } \\
\text { interval }\end{array}$ & $\begin{array}{l}\text { Plant } \\
\text { height }\end{array}$ & $\begin{array}{c}\text { Ear } \\
\text { height }\end{array}$ & $\begin{array}{c}\text { Flag leaf } \\
\text { area }\end{array}$ & $\begin{array}{c}\text { Ear } \\
\text { length }\end{array}$ & $\begin{array}{c}\text { Kernel } \\
\text { rows cob }^{-1}\end{array}$ & $\begin{array}{c}100 \\
\text { Kernel } \\
\text { weight }\end{array}$ \\
\hline Days to anthesis & $0.92 * *$ & & & & & & & & & \\
\hline $\begin{array}{c}\text { Anthesis silking } \\
\text { interval }\end{array}$ & $0.38 * *$ & $0.41 * *$ & $0.56 * *$ & & & & & & & \\
\hline Plant height & 0.02 & 0.10 & 0.06 & 0.06 & & & & & & \\
\hline Ear length & 0.03 & -0.11 & -0.10 & -0.04 & -0.12 & 0.20 & 0.24 & & & \\
\hline Kernel rows cob-1 $^{-1}$ & $0.25 *$ & $0.30 *$ & $0.25 *$ & 0.02 & $0.57 * *$ & 0.20 & 0.03 & 0.03 & & \\
\hline 100 Kernel weight & 0.03 & 0.10 & 0.13 & $0.30 *$ & $0.38 * *$ & 0.10 & $-0.46^{* *}$ & -0.09 & $0.25 *$ & \\
\hline Grain yield & -0.20 & $-0.25^{*}$ & $-0.30 *$ & $-0.28^{*}$ & 0.23 & $0.41 * *$ & 0.03 & $0.45 * *$ & 0.05 & 0.21 \\
\hline
\end{tabular}




\section{Conclusion and recommendations}

Significant variability among the hybrids for the studied traits indicated that selection would be effective. Hybrid 1 showed high kernel rows per cob, 100 kernel weight and grain yield, and could be recommended for commercial cultivation under agroecological condition of Peshawar. Grain yield had positive association with plant height, ear height, ear length, flag leaf area, kernel rows cob-1 and 100 kernel weight. Therefore special attention should be given to these traits in selection to achieve high productivity.

\section{Authors' contributions}

Conceived and designed the experiments: $\mathrm{H}$ Rahman, Performed the experiments: A Izzam, Analyzed the data: A Sohail, Contributed reagents/ materials/ analysis tools: S Ali, Manzoor \& Q Hussain, Wrote the paper: A Sohail.

\section{References}

1. Golbashy M, Ebrahimi M, Khorasani SK and Choucan R (2010). Evaluation of drought tolerance of some corn (Zea mays L.) hybrids. Iran Afr J Agric Res 5(19): 2714-2719.

2.

FAO

(2015)

http://www.fao.org/inpho/maize.

3. Grzesiak S (2001). Genotypic variation between maize (Zea mays L.) singlecross hybrids in response to drought stress. Acta Physiol Plant J 23(4): 443456.

4. Signor EL, Dousse CSJ, Lorgeou JB, Denis R, Bonhomme P, Carolo, and Charcosset A (2001). Interpretation of genotype $\mathrm{x}$ environment interactions for early maize hybrids over 12 years. Crop Sci 41: 663-669.

5. Bocanski J, Sreckov Z, \& Nastasic A (2009). Genetic and phenotypic relationship between grain yield and components of grain yield of maize (Zea mays L.). Genetika 41(2): 145-154.
6. Haq NM, Saad IM, Mozamil H, Sajjad URC, Habib IJ (2005). Genetic correlation among various quantitative characters in maize (Zea mays L.) hybrids J of Agric Society 1(3): 262265.

7. Yan W, and Kang MS (2003). GGE biplot analysis: A graphical tool for breeders, geneticists, and agronomists. 1st Edition, CRC Press LLC. Boca Raton, Florida, USA. pp: 271.

8. Ali Q, Ahsan M, Mustafa HSB, Hasan EU (2013). Genetic variability and correlation among morphological traits of maize (Zea mays L) seedling. Albanian J Agric Sci 12(3): 405-410.

9. Shah SS, Rahman H, Khalil IH, and Rafi A (2006). Reaction of two maize synthetics to maydis leaf blight following recurrent selection for grain yield. Sarhad J Agaric 22(2): 263-269.

10. Abdulla AE, Mahmoud MF and Naim AH (2010). Evaluation of some maize (Zea mays L) varieties in different environments of the Nuba Mountain of Sudan. Aust J Basic \& Appl Sci 4(12): 6605-6610.

11. Shakoor MS, Akbar M, \& Hussain A (2007). Correlation and path coefficients studies of some morphophysiological traits in maize double crosses. Pak J Agri Sci 44(2): 213-216.

12. Sabiel AI, Awadalla, Abdelmula A, Elfadil, Bashir MA, Baloch S, Baloch SK and Bashir W (2014). Genetic variation of flowering trait in maize (Zea mays L.) under drought stress at vegetative and reproductive stages. $J$ Bio Agri \& Healthcare 4(20): 117-122.

13. Ahmad SQ, Khan S, Ghaffar $M$ and Ahmad F (2011). Genetic Diversity Analysis for Yield and Other Parameters in Maize (Zea mays L.) Genotypes. Asian J Agric Sci 3(5): 385388. 
14. Duvick DN (2001). Biotechnology in the 1930s; the development of hybrid maize. National Review of Genetics 2: 69-74.

15. Qamar M, Gurmani ZA, Malik HN and Tanveer SK (2007). Evaluation of maize hybrids/synthetics under double cropping zone of northern areas of Pakistan. Sarhad J Agric 23(4): 10091012.

16. Rahman H, Arifuddin, Shah SMA, Iqbal $\mathrm{M}$ and Khalil IH (2010). Evaluation of maize S2 lines in testcross combination: Flowering and Morphological traits. Pak J Bot 42(3): 1619-1627.

17. Rahman R, Ali S, Shah SMA, Shah SS, Rahman N, Khalil IA, Hussain I and Afzal F (2008). Diversity for morphological and maturity traits in maize populations from Upper Dir. Sarhad. J Agri 24(3): 967-978.

18. Singha N and Prodhan SH (2000). Character association in green maize. Env Eco 18(3): 962-965.

19. Allen JR, McKee GW and McGahen JM (1973). Leaf number and maturity in hybrid corn. Agron J 3(6): 233-235.

20. Martin MJ and Russel AW (1984). Correlation response of yield and other agronomic traits to recurrent selection for stalk quality in maize synthetics. Crop Sci 24: 746-50.

21. Carlone MR and Russell WA (1989). Evaluation of S2 maize lines reproduced for several generations by random mating within lines II.
Comparisons for test cross performance of the original and advanced S2 and S8 lines. Crop Sci 29(4): 899-904.

22. Rafiq CM, Rafique $M$ and Hussain A (2010). Studies on heritability, correlation and path analysis in maize (Zea mays L.). J of Agric Res 48: 1-35.

23. Umakanth AV, Satyanarayana E and Kumar MV (2000). Correlation and heritability studies in Ashwini maize composite. Ann Agric Res 2(1): 228-30.

24. Altenbas $M$ and Algan N (1993). Correlation among earliness, yield, yield components and quality traits in hybrid maize. Anadolu 3(3): 40-62.

25. Rahman MM, Ali MR, Sultan MS and Mitra MK (1995). Correlation and path coefficient studies in maize (Zea mays L.) composites. Bangladesh J Sci Ind Res 30: 87-92.

26. Nizam-uddin, Qasim $M$ and Hussain $M$ (2010). Comparative study of agronomic parameters in synthetic maize varieties. J Agric Res 48(1): 5357.

27. Tahir M, Tanveer A, Ali A, Abbas M and Wasaya A (2008). Comparative Yield Performance of Different Maize (Zea mays L.) Hybrids under Local Conditions of Faisalabad-Pakistan. Pak J life Soc Sci 6(2): 118-120.

28. Iqbal RM and Chauhan HQI (2003). Relationship between different growth and yield parameters in maize under varying levels of phosphorus. J Biol Sci 3: 921-925. 